\title{
8
}

\section{GOVERNMENT AND CORRUPTION IN NIGERIA! A GENERAL EXPRESSION*}

\author{
Antonia T. Okoosi
}

\begin{abstract}
It Is widely acknowledged that my society plagued by corruption is a nation in distress. The article observes that Nigeria is unfortunately in such a situation as virtually all spheres of its public life is affected by the vice. The article rakes pertinent issues about the role of a government in corruption in Nigeria and concludes that government has, in fact, aided and abetted (through inaction) rather than try to check corruption. A brief characterization of various regimes and their efforts or otherwise to curb the menace is enunciated with more emphasis on the period between 1986 and 1993 when the situation seemed to worsen. A general impression of the factors which engenders corruption and corrupt practices is identified while a critique of official means of dealing with corruption is also attempted.
\end{abstract}

\section{INTRODUCTION}

This paper intends to raise issues on what government has done about the problem of corruption in Nigeria particularly between 1986 and 1993 as, it is in looking at the past that one can place the present and future in proper perspective. Furthermore, it is imperative to start from and with government because it $\mathrm{k}$ a truism that government which is supposed to fight and defeat corruption is the kernel of the problem in Nigeria. The Centre for Advanced Social Science put it succinctly when it said:

* (A revised version of the paper presented at the CASS Seminar on Corruption, Port-Harcourt, 2-4 December, 1993. The author wishes to acknowledge Attahiru Jega's work on the subject for the Seminar which provided useful theoretical base for this revision.) 
Nigeria: Government and Corruption 111

The problem is that the government which is needed to defeat corruption is the core of the problem in Nigeria. It is government that has contributed most to lowering the moral tone of society in Nigeria. It $U$ in government that corruption thrives most, wasting resources we need, defeating all prospects of democracy and development, all sense of patriotism and turning all of us into hardened cynics with no concern for the public good, no faith in public morality or even in its possibility.

It is only appropriate, therefore, that a thorough look at the problem should begin with an incisive examination of government itself. To achieve this objective, Section Two of the paper contains theoretical perspectives in which some postulations, causes and forms of corruption are briefly enunciated. The third Section does an overview of corruption in the country, using the period under Military President Ibrahim Babangida as a focus. Government provisions for alleviating the problem of corruption are evaluated and some proposals made for the purpose in Section Four, while the last Section concludes the paper.

\section{THEORETICAL PERSPECTIVES: CAUSES AND FORMS OF CORRUPTION}

Like many social science concepts, a concise and widely accepted definition of corruption is almost impossible for it depends oftentimes on which side and how it is to be examined and for what purpose. The first, second and fifth definitions of corruption in the World Book Dictionary explains it as the act of making, or the process of becoming evil of wicked; bribery, dishonesty, it is also seen to be synonymous with rot and decay. It is obvious that all that corruption does to any country or system is to have negative impacts on it.

Heidenheimer (1978) has identified three variants of the phenomenon, based on the objective they set out to achieve. These are public office centred, market-centred, and public interest-centred corruption. Public office-centred corruption is seen to deal with abuse of public trust and official positions and responsibilities for self-serving objectives. Oftentimes, this would not result in monetary gains as, for example, when the head of an organization or country employs or appoints someone based on personal relationship rather than merit. When public office is converted into an avenue (or the maximization of income and/or property as in the case of the Osborne Road land scandal, market-centred corruption has occurred. Public-interest centred corruption emphasizes the abuse of public trust to serve cliental cleavages, communal and other group interests, as for instance, the sitting of an airport by the Nigerian Airways in an obviously unviable town or route, simply because it is the capital of the Managing Director's state of origin.

Though corruption exists the world over, it is wantonly indulged in and therefore more devastating in neo-colonial dependent capitalist countries like Nigeria. Thus, it is not surprising to find all the three categories stated above manifesting themselves in the Nigerian society, considering that corruption 


\section{Annals of the Social Science Council of Nigeria, No.5, 1993}

operates at both individual and group levels. In particular, government and administration account for the greatest part of its manifestations for the simple fact that leadership and the bureaucracy are the major avenues through which resources for developmental purposes are channelled. The situation is further the case considering the over-developed and robust constitution of the state coupled with the prebendal character of politics in Nigeria. This peculiar character is manifested among others in the spoils system and prevailing patronclient relations entrenched in community values and beliefs. Thus, for our purpose, it is plausible to define corruption as the misuse of power or (public) office by those in positions of authority on any public trust for personal or group gain or end in whatever form monetary or otherwise.

It can be argued that the disdain for corruption is felt mainly on grounds of morality. It is in this light that some scholars argue that it is the backwardness or complete lack of (positive) societal values and cultures relating to morals that allows corruption to thrive in less developed countries. Conversely, the high level of development of these moral values and cultures in developed countries is seen to account for the reduced level of official corruption, particularly of the market and public interest-centred specie.

A systemic and structralist postulation of corruption explains it on account of the 'inadequate and inappropriate' 'modernization' (dependent) 'development' premises on which the state bureaucracy is founded. This view is shared by Onoge who contends that the nature of Nigeria's capitalism (the fact of its being in the primitive accumulation stage) creates a cultural condition of anomie which is, in turn, a fertile ground for aspiring capitalists to squeeze out social surplus from precapitalist formations and values, Additional political factors facilitating the movement of corruption in public life arise from the alienated colonial origins of the state whereby public officials are able to manipulate ethno-cultural cleavages in society and continue to relate to the people as colonial forces of corruption.

The neo-colonial structures and processes which gave birth to the Nigerian State facilitate 'elite hegemony" and the emergence of a bureaucracy interested only in the interests of the elites. These processes also make the economy dependent capitalist, and the state the major source of accumulation. Thus, the struggle is for control for accumulation purposes and therefore corruption. Under military regimes, Bienen and Fitton argue that the political and administrative contexts in which public officers, particularly civil servants operate and which gives them "greater freedom of action... has made them more vulnerable to charges of corruption".

Corruption flourishes whenever the citizenry is politically powerless and unorganized. However, a political mobilization of the people towards democratic participation can act as a check against bad government as well as corruption by government and public officials. ${ }^{10}$

In Nigeria, corruption and corrupt practices exhibit themselves in day-to-day activities, yet it is almost impossible to place a hand on it due mainly to its very nature. It is a matter that cannot be freely debated without emotion. Even where it can be objectively discussed, it cannot be established (beyond reasonable doubt), let alone to $\mathrm{y}_{\mathrm{y}}$ be published. Cases of political 
corruption, for instance, are often shrouded by those supposed or expected to investigate and expose them. Discussion has, can and will always be hindered by the regime of the day, while the lack of access to relevant files and documents often makes investigation and therefore proving and ultimately making findings available to the public impossible. Despite this, the commonest presentations of corruption and corrupt practices can be seen in abuse of office through extra-budgetary expenditure often aimed at gaining popularity or currying favour or support. This is the public interest-centred type. Market-centred corruption shows itself in terms of the creation of 'ghost' workers; kick-backs and commissions on government projects and purchases; illegal oil sales and auctioning of public property, ranging from cars to seized goods; fraud, forgeries and graft; and bribery. Nepotism and inappropriate job placements are examples of public officecentred corruption in Nigeria.

\section{CHARACTERIZING CORRUPTION IN NIGERIA'S POLITICAL REGIMES}

It is part of our political history that successive Nigerian regimes have recognized corruption in public life as a major problem and have attempted to do something about it. Military regimes/coups in particular have sacked their predecessors on grounds of being corrupt or being unable to curb corruption.

The Murtala/Obasanjo administration seized properties of corrupt public officers and dismissed public officers who had been found to have misused their offices. The Shagari administration to which it handed over introduced the ethical revolution and the Buhari/Idiagbon duo are famous for the war they waged against indiscipline (WAI) bothering upon corruption and misuse of public office. Following its overthrow, the new administration under General Babangida inaugurated in 1989 a committee on corruption and other economic crimes in Nigeria. Following the truncation of Nigeria's march to the Third Republic and the imposition of an interim government, the Head of State - Chief Shonekan - made efforts through a proposal to the National Assembly on how to curb corruption in Nigeria. His subsequent resignation and take-over by General Abacha has seen the administration also making efforts at curbing corruption via among others, the institution of probe panels into many government agencies and parastatals.

Despite all the above, the situation rather than improving is worsening. Under the Shagari regime, corruption did not subside but thrived resulting in the alienation of the citizens from the ruling elite. Some hope for rejuvenation seemed to be in the offing upon the take-over of the military in December 1983. However, the regime had a short lifespan for its impact to be deeply felt in this area. However, 'in its twelve months, many public officials were indicated and some semblance of sanity seemed to be returning to the polity. Under President Ibrahim Babangida, however, it is instructive to note that the administration did not find the time to deal with the Report submitted by the Kayode Eso committee it set up. At the end of its rule, the regime had condoned rather than try to curb corruption. The Interim Government's life 


\section{Annals of the Social Science Council of Nigeria, No.5, 1993}

was short-lived to make any impact on the society having been preoccupied with dealing with its legitimacy problem. The efforts of the present administration are, to $\mathrm{ah}^{1}$ intents and purposes, haphazard, pretentious and selective, making it impossible to be considered serious, bearing in mind its desire to deal with corruption only onwards but not before.

Thus, the corruption situation rather than subside, worsened, to the extent that in Nigeria today it is widely acknowledged that one of the easiest and fastest ways to 'make it', or 'arrive' etc. is to join government service or accept a government appointment, because of the big business that such constitutes. The other related ways are to either defraud government, or circumvent a (government) law with all those concerned turning a blind eye. Even members of the armed forces, having been politicized and corrupted, today prefer political appointments to military ones. ${ }^{11}$

Two questions easily come to mind. One, why is it that in Nigeria the very fact of occupation of public office means or translates into being corrupt? This question is important because oftentimes the very fact of occupation (of public office) guarantees certain official or unofficial perquisites even from the public itself. It commands certain undefinable respect and deference (with all the material benefits) whether warranted or not, which, in the long run, breeds corruption and corrupt practices. Two, at what point does gratification stop and corruption begin? This is considered important for the fact that gratification is an important element of everyday living, particularly where competition pervades and resources are scarce as in the case in Nigeria today.

Brazen corruption was more the vogue than the exception in the last eight (19861993) years in particular. It was a season in which little or nothing was done to restore any sanity into the system in terms of curtailing corruption and corrupt practices. Instead, the disease was provided fertile ground to spread as seen in the many activities of the government of the day. Its extra budgetary generosities (for instance, to organizations), its era of favours and 'settlements' (courtesy General Obasanjo) were activities border ing on corruption and misappropriation of public funds.

Government's poor record of accountability amongst public officers was during that period the bane of Nigeria's corporate life, taking for instance, the National Electoral Commission (NEC), the National Drug Law Enforcement Agency (NDLEA), the Nigeria Telecommunications PLC (NITEL),. and the Nigeria National Petroleum Corporation (NNPC). ${ }^{12}$ A brief look at the NNPC's case in useful here. Recent developments and newspaper publications show a lot of corrupt practices have been going on at the nation's biggest foreign exchange earner. The most recent case involved a project which committed Nigeria to hire four tankers to store, in an interim arrangement, petroleum products imported through the Lagos port. This need to import was based on the established fact that the nation's four refineries in Port Harcourt, Warri and Kaduna are beset with problems ranging from inefficiency to deficiency. The problem of fuel scarcity was therefore to be addressed by importation. This was during Chu Okongwu's tenure.

His successor, Philip Asiodu, saw a solution slightly differently. He 
thought it better to buy outright rather than hire the tankers. It was in the process that payments for hiring were to be suspended so that arrangements for purchasing could be processed. He could not complete this assignment when Don Etiebet took over as Minister. Barely one week into office and during a one-week trip to Geneva for an OPEC meeting, payment for $\$ 41$ million was made and completed for the hiring of tankers.

A number of questions easily come to mind from this whole episode regarding the propriety of acquiring foreign facilities and materials for the NNPC. Some of these include:

(i) Why does the nation's biggest industry not keep any or proper records/accounts of its activities?

(ii) Why and how did a project which is not in the best interest of the Corporation and which does not have the best intentions for the nation get approved in the first place?

(iii) Relatedly, how could hiring storage tanks for imported petroleum products sound more sensible that outright purchase (of the tankers), or better still, the use of available funds to repair damaged or dysfunctional refineries?

(iv) How and why did suspected and involved officials of the NNPC already on suspension, suddenly get retired with full benefits when their case was still pending in court?

(v) How did (and could) the NNPC case already in the court be withdrawn so abruptly only to be transferred to the Miscellaneous Offences Tribunal?

(vi) How could the reliefs sought by the accused persons' lawyers that the accused men not be re-arrested by the Police, the State Security Service (SSS), the Directorate of Military Intelligence (DMI), the Nigerian section of International Police (Interpol) and any other government controlled law enforcement agency, until they are ready to prosecute them before the tribunal, be favoured?

Attempts to provide answers to these questions would surely expose the kind of rot and decay that pervades the NNPC among other government agencies. This was created and entrenched by apparent official condonement of corruption.

Government turned a blind eye to corruption by disregarding or trivializing it, thus giving tacit support to its blossoming by not taking drastic steps to punish or make scapegoats of public officers accused and found guilty of corrupt practices. The celebrated Ms Jennifer Maduike/ Fidelis Oyakhilome of the NDLEA case, the Peoples' Bank/Tai Solarin case, the Governor Maina of Borno State and the case of Rivers State Governor and the Alhaji Bashir/Vice-President Augustus Aikhomu case are all instances in which government virtually defended its officials without prior investigation. In the latter case, rather than set up a probe panel, Alhaji Bashir was locked up under Decree 2 and later let loose.

In a 1992 paper to the Nigerian Political Science Association (NPSA) in ASCON, Badagry, this author wrote on an assessment of the famous Political Transition Programme (FTP) of the last administration: 
Most significant in all this is government's tacit support for corruption. Government officials are asked to ensure accountability and not necessarily not to be corrupt. These are two different but similar calls... Instead, it (government) comes out often in defence of such officers. Hence, corruption, so trite within the present dispensation, is the deal in vogue being carried out with more fanfare and pomposity. The system is further characterized by patronage, rewarding and punishing.

It is the popular view that up and until 1993, President Babangida did not make corruption the theme of any of his public statements. Neither did the word feature prominently in the administration's affairs. Thus, it is easy to conclude that it (corruption) never was an issue to the administration unlike its immediate successor administration the Interim National Government (ING). Of course, a mere mention or even repeated mentioning of the word does not necessarily translate to action, as seen in the fact that with all the hue and cry about corruption by the ING, its head was himself, among many other public officers, a shareholder in the Osborne Road land scandal!

The last administration also encouraged corruption when it promulgated various decrees returning various properties earlier seized from some past officials, including dead ones, who had property in excess of their legitimate earnings. Some of the Decrees include No. 49 of 1991, No. 70 of 1992 and No. 24 of 1993. ${ }^{15}$ A last one, No. 54 of 1993, was promulgated only a few days to its demise. This was in a bid to get some of the beneficiaries (semi-gods in their various regions) to canvass for public support for the administration to extend its tenure. These kinds of actions are prone to encourage public officers to disregard calls for probity and accountability in government since there exists the possibility of regaining any seized property (it may as well be seen as being kept in trust) in the future, depending on the mood of the government of the day. By extension, it is also possible for a public officer to corruptly enrich himself, and upon being accused, flee the country and return after a few years (to his booty) when all would have been forgotten and a times even get pardoned by the state. Regarding the return of seized properties to their owners, it should be observed that some of these properties are, and have been, returned without consideration for the additional expenditure (to the detriment of tax-payers) that have been incurred on them whilst being forfeitures.

The present administration of General Sani Abacha which aims to fight corruption with its War Against Indispline and Corruption (WAIC) as well as its reconstituted National Orientation Agency (NOA), is only groping in the dark. This is because a genuine antidote for the disease should have started with and from within itself. It has not been declared that those currently at the helm of affairs have declared their assets and it is instructive that some of its officers are men who have been indicted by probe panels in the past ${ }^{16}$ The administration has also recently promulgated Decree No. 118 - Forfeiture of Assets (Release of certain forfeited properties, etc.) - signed into law on 30 December, 1993 by the Head of State which also returned certain seized properties to their owners. 
Nigeria: Government and Corruption 117

\section{WHAT ARE GOVERNMENT PROVISIONS FOR DEALING WITH CORRUPTION IN NIGERIA?}

The Code of Conduct Bureau which supervises public officers declaration of assets and the enforcement of Code of Conduct for public officers and the use of tribunals (and its regular courts) in trying public officers suspected of corrupt enrichment are the dearest formal instruments available to government in the present dispensation and since the 1979 Constitution. Section 15 of the Code of Conduct Bureau and Tribunal Decree No. 1 of 1989 stipulates that every public officer will within IS months after coming into force of the Decree (January 1,1988) or immediately after taking office and thereafter at the end of every four years or at the end of his term of office, submit to the Bureau a written declaration of all his property, assets and liabilities and those of his spouse or unmarried children under the age of 21 years.

These provisions are inadequate, for they still have not been able to curb corruption. There are no clear steps, aside from verbal threats, to be taken when a public officer deliberately does not complete an asset declaration form at the beginning or/and end of his service. There also exist situations where public officers acquire property in excess of their legitimate income in the name of a trusted family member or friend, but which is publicly known to belong to the public official. This raises the issue of authentication. Tribunals rather than regular courts are also not the best avenues of establishing the innocence or guilt of those arraigned before them. And finally, there has not been any examples made of, or swift and decisive actions taken against erring public officers, even where tribunals or regular courts have found them guilty. The solution to the problem of corruption must take sanctions very seriously as a first step to addressing the problem. A decongestion of the Federal Centre also needs to be considered. Alongside this is an urgent need for societal re-orientation and re-socia- lization for awareness about corruption. Above all, a good leadership and government needs to be evolved without which any efforts at curbing corruption would be fruitless. This returns us to the fact that curbing corruption in government is a first step to sanitizing the whole society.

\section{CONCLUSION}

It is clear that what have begun as an illegality has gradually advanced into a social process. The rot and decay have set in, largely inordinately and uncontrollably. It is imperative that one admits that there is an inextricable connection between politics and corruption. The latter should not, however, be elevated to the status of an instrument of state policy especially as it is a vice. Unfortunately, the kind of strong centre Nigeria operates unconsciously incubates the vice. Furthermore, the negative, harsh and biting effects on the population of economic policies, either in the form of austerity measures or structural adjustment programme, make it easy to dominate the population in an environment characterized by abject poverty. It is not surprising, therefore, that our kind of society, very averse to materialism, is very prone to corrupt practices. 
118 Annals of the Social Science Council of Nigeria, No.5, 1993

\section{REFERENCES}

1. Centre for Advanced Social Science Brief to Participants for the Seminar on Corruption, Port-Harcourt, December 2-4,1993.

2. Thorndike-Barnhart, World Book Dictionary. Field Enterprises Educational Corporation, London.

3. A. Heidenheimer (ed), Political Corruption, Readings in Comparative Analysis, New Jersey, 1977, pp. 3-30.

4. $\quad$ S.H.C. Alatsa, Intellectuals in Developing Societies, Frank Cass: London, 1977.

5. L. Diamond, Class, Ethnicity and Democracy in Nigeria, Macmillan: London, 1977: R. Josephy, Democracy and Probendal Politiks in Nigeria: The Rise and Fall of Nigeria's Second Republic, Oxford University Press, 1986.

6. Alatsa, op. cit.

7. W. O. Graf, The Nigerian State, James Curry, London, 1988, p. 216.

8. O. F. Onoge, "What is to be done about Corruption in Government". Paper presented at the CASS Seminar on Corruption, Port-Harcourt, December 2$4,1993$.

9. Bienen and Fitton, in Panter-Brick, K. Soldiers and Oil, Frank Cass: London, 1978, p. 50.

10. Directorate for Social Mobilization, Political Education Manual, Abuja, 1989, pp. 17-21.

11. See, former Chief of Army Staff, General Salimu Ibrahim's statement at the occasion of the Regimental Dinner in his honour, where he described the Army as one of "Anything is Possible", The Guardian on Sunday, September 19,1993, p. 9.

12. See, African Guardian, Monday, November 1, 1993; The Guardian, Monday, October 18,1993; Newswatch, Monday, October 29,1993.

13. A. T. Okoosi, "The Political Transition Programme, 1987-1992: An Assessment". Paper presented at the 19th Annual Conference of the Nigerian Political Science Association (NPSA), ASCON, Badagry, December 14-16,1992.

14. The Guardian, Wednesday, October 13,1993; The Guardian, Saturday, November $6,1993$.

15. African Concord, March 7,1994, p. 29.

16. Dr Samuel Ogbemudia, former Bendel State Civilian Governor and present Labour Minister was one of the beneficiaries of the Reprieve Granted by Decree No. 54 of 1993.

17. African Concord, op. cit. 